\title{
Reforming International Investment Law in a Transitional China: The Post-FPS of the 18th Party Central Committee
}

Qiang Ren ${ }^{* *}$

This paper examines the new trends of interaction between the legal transformations in China and the international investment treaties, focusing on the legal reforms after the Fourth Plenary Session of the Eighteenth Party Central Committee Fourth Plenary Session of the 18th Party Central Committee of the PRC of 2014 (2014 FPS). It envisages that the 2014 FPS will impose significant influence on the current legal system in China, on the forthcoming Foreign Investment Law of China, and eventually on the negotiation and application of the international investment treaties concluded by China because the CPC Central Committee Decision on Certain significant Issues regarding the Comprehensive Promotion of Law (PCC Decision) has demonstrated the directions of legal constructions and reforms explicitly and comprehensively from the administrative, judicial, social, and jurist perspectives, which constitutes the most inclusive PCC Decision regarding Chinese law and justice.

Keywords: IIAs, Legal reforms in China, FPS, Party Central Committee Decision, BITs

* This paper is fully revised and updated version of the author's doctoral thesis (Chapter 2) submitted to the University of Liverpool.

** Ph.D. candidate at the University of Liverpool, UK. LL.B./LL.M. (CUPL). ORCID: http://rcid. org/0000-0003-3146-7300 The author is grateful for Professor Fiona Beveridge and Dr. Mavluda for their encouragement and insightful comments on earlier drafts of this article. All errors are the author's own responsibility. The author may be contacted at: q.ren@liv.ac.uk / Address: 1.21, Mulberry Court, Vine Court, 35 Myrtle Street, University of Liverpool, Liverpool, L7 7AJ, UK. 


\section{INTRODUCTION}

Since 1982 when the first Chinese BIT was concluded, nearly 150 BITs have been reached between China and other contracting States. Although it is difficult to conclude to what extent the BITs are promoting FDI flows, ${ }^{1}$ undeniable is that the BITs provide comprehensive protection of investment and improve the economic determinants of FDI flow. ${ }^{2}$ Meanwhile, the number of investment disputes under the Chinese BITs has been increasing since 2008. It is mainly due to the expanding cross-border investment activities and the merging third generation of Chinese International Investment Agreements ("IIAs"), although the results of most disputes remain to be seen. ${ }^{3}$

For a long time, Chinese BITs were mainly modeled after the US and Canadian BITs. The reforms of Chinese domestic laws, however, have not been involved in treaty negotiation. ${ }^{4}$ When, the China-Canada BIT and China-Japan-Korea Trilateral Investment Treaty reached in 2012, they demonstrated that the interests of the host countries are being taken into account in IIAs more. ${ }^{5}$ The Premier of State Council in China maintained that 'mutual balance' should be reflected in the ongoing negotiation of the China-US BIT, ${ }^{6}$ indicating the desire to consider Chinese interests in the new treaty.

As a result, Chinese laws, in particular the will-be-reformed laws after the 2014 Fourth Plenary Session ("FPS") ${ }^{7}$ are likely to influence the negotiation and application of the future Chinese BITs. Here, a question may arise as to what extent the post-2014 FPS legal reforms will affect Chinese IIAs and the ongoing China-US and China-EU investment instruments.

The primary purpose of this research is to fill the literature gap regarding the interplay of IIAs and Chinese domestic laws in transition. This paper is composed of five parts including a short Introduction and Conclusion. Part two will examine the recent developments of Chinese BITs. This part revisits the treaty practice in China and proposes 2012 rather than 2008, as the watershed of a new generation of Chinese BITs seeking the balance between investors and the host countries. Part three will evaluate the PCC Decision reached from the 2014 FPS as well as the possible development of the legal system in China arising from the PCC Decision. Part four will explore the impacts of post-2014 FPS legal reforms on Chinese IIAs negotiation and application. Part five will reach the conclusion. 


\section{New Development of Chinese BITs}

Like the majority of the existing 2923 BITs across the globe, ${ }^{8}$ Chinese BITs are signed to protect and promote cross-border investment activities. Substantive obligations of the host countries are included in BITs provisions to protect foreign investment such as the national treatment, most-favored-nation treatment and fair and equitable treatment. Procedural dispute settlement mechanisms are provided in BITs as well through which international investors are entitled to claim the host countries under the ICSID/UNCITRAL or ICC frameworks. With the investmentfriendly substantive and procedural protection mechanisms for international investors, the host States may end up with huge compensation for the breach of BITs obligations. ${ }^{9}$

China has concluded 146 BITs $^{10}$ with 132 countries until March 24, 2013, when the China-Tanzania BIT was signed. Apart from the 146 BITs, 19 more investment instruments have been concluded as well until June 17, 2015, including framework agreements, free trade agreements, partnership agreements and trilateral investment agreements. ${ }^{11}$ Accordingly, foreign investors from developing as well as developed countries can be protected under the international investment agreements in China.

However, the parallelism between the protection of Chinese investors abroad and foreign investors in China, and that between the protection of investors' private rights and the protection of the host countries' public interests have been changing in the development of Chinese BITs since 1982. It may be categorized into three stages: stage one from 1982 to 1998; stage two from 1998 to 2012; and stage three from 2012 till now. Each stage is marked by an effort to uphold the interests in the two parallelisms above but with different emphasis. It is noteworthy that the balance has been especially called for since 2012, which might be reflected in the numerous emerging BITs concluded by China.

\section{A. Conservative and cautious towards investment protection: 1982 to 1998}

Since launching the "Reform and Opening-up Policy" in 1978, China has made miraculous and breathtaking economic growth. ${ }^{12}$ The Reform and Opening-up Policy was decided by the Communiqué of the Third Plenary Session of the 11th PCC in 1978, which stressed that: "Global economic cooperation is needed in 
China upon equity and mutual benefits and global advanced tech and equipment should be introduced into China." Accordingly, special economic zones were established in Guang Dong and $\mathrm{Fu}$ Jian provinces as pilot regions where numerous flexible regulations were adopted to facilitate the labor-intensive processing export industry.

The Reform and Opening-up Policy was implemented in the areas of trade, investment, technology, service, etc. Following the Policy, China tried to enforce international investment. However, the first Chinese BIT was concluded 4 years later in 1982 with Sweden. Up until 1998, 87 BITs were concluded, accounting for nearly 60 percent of all the BITs (146) signed by China. The BITs between 1982 and 1998 were regarded as the first generation BITs ${ }^{13}$ which provided narrow dispute resolution regarding only the amount of compensation for expropriation. ${ }^{14}$

Some research reveals that Chinese people would have negative attitudes towards litigation. ${ }^{15}$ As this traditional tendency was reflected particularly in Chinese BITs between 1978 and 1998, China did not favor international judicial mechanism to resolve investment disputes. ${ }^{16}$ China has concluded BITs with 87 countries, but no international dispute settlement case was reported involving China in the past. Although the liability of China as the host country was limited due to the narrowed dispute settlement provision, Chinese investors abroad are well protected.

\section{B. Increasing Protection for Investment: 1998-2012}

Between 1998 and 2012 the national agenda of economy shifted from 'Promoting Importing' to 'Going Global (2000),' presenting a trend to boost the economic development more actively. Since 1979, the State Council of China has initiated "Establishing Enterprises Abroad" to implement the Opening-up Policy. For the first time, the conception of 'investing abroad' was formulated as a national policy. ${ }^{17}$ The Going Global policy was advocated in third Session of the Ninth National People's Congress in 2000, but it was not stipulated formally until the Sixth Plenary Session of the Fifteenth PCC in $2001 .{ }^{18}$ In drafting the Tenth FiveYear Plan ${ }^{19}$ by the Central Committee, 'Going Global' was one of the four national strategies with the Development of Western Regions Strategy, Urbanization Strategy, and Talent People Strategy. The Going Global policy is still influential to the Chinese economic and investment policy even accelerating through "Further 
Going Global" in the eleventh Five-Year Plan (2006-2010) ${ }^{20}$ and "Fasten the Implementation of Going Global" in the twelfth Five-Year Plan (2011-2015). ${ }^{21}$

The Going Global policy was not only attracting foreign investment, goods, skills and technology, but also investing abroad and exporting capitals. The China-Barbados BIT 1998 reflected the Going Global requirement in the area of international investment law. This BIT fully accepted the role of the ICSID as a means of international investment dispute settlement. It was thus regarded as a milestone ${ }^{22}$ in Chinese BITs to provide unrestricted access to international arbitration, which was followed by many Chinese BITs. ${ }^{23}$

As China joined the WTO as the 143rd member in 2001, Chinese investors were further integrated into the global market. In order to protect domestic investors abroad, Chinese BITs began to provide more flexible protection to foreign investors. On the one hand, fifty-one BITs were concluded with countries across Europe, Africa, America and Asia. On the other, a number of old BITs were amended Germany (1983), France (1984), Finland (1984), the Netherlands (1985), and Spain (1992). ${ }^{24}$

When comparing with the BITs between 1982 and 1998, the new BITs of 1998-2012 were much more developed. First, new provisions covered more crossborder investments. E.g., the consultation mechanism was adopted by China and Germany. ${ }^{25}$ Since the contracting party is entitled to propose consultations regarding the interpretation, application and implementation of the BIT, the two countries will obtain further flexibility for protecting their investors. The right to propose consultations is strengthened because the other party 'shall' consider the proposal as a compulsory obligation; it suggested that the treaty provided explicit mechanism of consultations preserving States' power to clarify the protection for investors. $^{26}$

Second, the specific provisions were stipulated for investment protection with more details. As for the general protection and promotion of investment, the China-Germany BIT 1983 provided equal and fair treatment. The China-Germany BIT 2003, however, demanded more protection including sustainable protection and security against discrimination and arbitariness. The instrument reified the protection from the angles of management, maintenance, use, enjoy and dispose of investment. ${ }^{27}$ The provision of expropriations granted greater protection for the investors in the China-Germany BIT 2003. Expropriations were prohibited 
in 1983; they were permitted only for public interests with due compensation pursuant to legal procedure. The 2003 BIT, however, did not require the 'legal procedure' among them. The new BIT provides details regarding the compensation as follows:

Compensation shall be equivalent to the value of the investment immediately before the expropriation is taken or the threatening expropriation has become publicly known, whichever is earlier. The compensation shall be paid without delay and shall carry interest at the prevailing commercial rate until the time of payment. $^{28}$

Not only the compensation is thus required to recover to the value of investment before expropriation, but also the interest at the prevailing rate is required to calculate compensation. It is noteworthy that the States' power and discretion were observed as well to facilitate the compensation by stipulating that: "At the request of the investor the legality of any such expropriation and the amount of compensation shall be subject to review by national courts, notwithstanding the provisions of Article 9." ${ }^{29}$

Third, international dispute settlement under the ICSID was introduced to treaties regarding the disputes between investors and the host countries. The China-Germany BIT 2003, e.g., provided that:

The dispute shall be submitted for arbitration under the Convention of 18 March 1965 on the Settlement of Investment Disputes between States and Nationals of Other States (ICSID), unless the parties in dispute agree on an ad-hoc arbitral tribunal to be established under the Arbitration Rules of the United Nations Commission on the International Trade Law (UNCITRAL) or other arbitration rules. $^{30}$

Hence, the investors from China and Germany can rely on the rules of the ICSID or UNCITRAL explicitly to resolve investment dispute, which was not stated in the old China-Germany BIT. Moreover, the awards reached under these rules were regarded as final and binding; they were only subject to "those appeals or remedies provided for in this Convention," ${ }^{31}$ which enhanced investors' rights from the legal authority of tribunals' awards. 
The Chinese BITs in the period of 1998-2012 illustrated pro-investment trend through providing substantive and procedural protections for investors and investments, which might be the reflection of liberal-investment principle. Being different from the cautious BITs between 1982 and 1998, the second generation of Chinese BITs provided opportunities to promote investments between China and other countries. Chinese investments were therefore transformed, including some emerging side effects such as the sovereignty wealth fund.

\section{Seeking Balance: Post-2012}

China has been attracting FDI because of its huge investment market. The FDI inflow into China demonstrated continuous growth in and after the global economic crises. $^{32}$ (Table 1)

Table 1: C1 FDI Inflows 2006 - 2013 (Millions of US Dollars)

\begin{tabular}{c|c|c|c}
\hline Year Country & China & UK & US \\
\hline 2006 & 72715.0 & 156193.2 & 237136.0 \\
\hline 2007 & 83521.0 & 200039.2 & 215952.0 \\
\hline 2008 & 108312.0 & 89025.8 & 306366.0 \\
\hline 2009 & 95000.0 & 76300.9 & 143604.0 \\
\hline 2010 & 114734.0 & 49616.9 & 198049.0 \\
\hline 2011 & 123985.0 & 51137.5 & 223759.0 \\
\hline 2012 & 121080.0 & 45796.0 & 160569.0 \\
\hline 2013 & 123911.0 & 37100.9 & 187528.0 \\
\hline
\end{tabular}

Source: OECD International Direct Investment Statistics 2014, available at http://dx.doi.org/10.1787/ idis-2014-en (last visited on Feb. 16, 2016).

Although the FDI outflow from China remains small when compared with the FDI inflow, a sharp boost of FDI outflow occurred in 2008, when it increased over 100 percent from USD 26,510 million to USD 55,910 million. With the huge foreign exchange reserves, ${ }^{33}$ China's FDI outflow keeps growing since 2006 without any cutbacks (Table 2). In spite of the impressive growth, China's FDI outflow remains small regarding its share in global FDI outflow market. ${ }^{34}$ Further FDI 
outflow from China is thus expected to be growing in the future.

Table 2: C2 FDI Outflows 2006 - 2013 (Millions of US Dollars)

\begin{tabular}{c|c|c|c}
\hline Year Country & China & Germany & US \\
\hline 2006 & 21160.0 & 118701.0 & 224220.0 \\
\hline 2007 & 26510.0 & 170617.5 & 393518.0 \\
\hline 2008 & 55910.0 & 72757.8 & 308296.0 \\
\hline 2009 & 56530.0 & 69638.8 & 287901.0 \\
\hline 2010 & 68811.0 & 126310.4 & 277779.0 \\
\hline 2011 & 74654.0 & 80971.1 & 386724.0 \\
\hline 2012 & 87804.0 & 79607.4 & 366940.0 \\
\hline 2013 & 101000.0 & 57549.6 & 338302.0 \\
\hline
\end{tabular}

Source: OECD International Direct Investment Statistics 2014, available at http://dx.doi.org/10.1787/ idis-2014-en (last visited on Feb. 16, 2016).

With regards to the bi-directional growth of FDI inflow and outflow, China is in the transition towards dual identity: capital exporting country and capital importing country. It requires China to balance her position as a home and as well as host country simultaneously. The cautious BITs during 1982-1998 and the investment-protection based BITs during 1998-2012 are therefore to be adjusted more progressively.

The China-Canada BIT and China-Japan-Korea trilateral investment treaty ("CJK TIT") adopted the provisions for protecting investors as well as the interests of the host countries, in order to achieve the balance between private and public interests. Standalone exception provisions ${ }^{35}$ and exceptions provided in the provision of States' obligations ${ }^{36}$ are adopted to reserve the regulatory space of the host countries through justifying governmental measures.

Apart from the exceptions on expropriation and compensation, ${ }^{37}$ the ChinaCanada BIT and the CJK TIT both provide more comprehensive exceptions. First, the exceptions cover broader treaty provisions more clearly. The China-Canada BIT 2012 precluded the most-favored-nation treatment ("MFN") in the free trade area, customs union and aviation, fisheries and maritime industry. ${ }^{38}$ In these specific 
areas, each party would have more flexible measures. Also, the procurement by a contracting party and government-supported loans, guarantees and insurance are all exclude from the MFN (Article 5), national treatment standard (Article 6) and the requirement of the "Senior Management, Boards of Directors and Entry of Personnel" (Article 7). ${ }^{39}$

Second, unlike the majority of the BITs before 2012, new BITs pay due attention to environmental protection, desiring to protect public interests of the host States. The China-Canada BIT and the CJK TIT both not only recognize high environmental standards to attract investment in preamble or consultation provisions, but also provide environmental protection mechanisms in substantive provisions. ${ }^{40}$ Regulatory power of the host countries is thus embodied explicitly in these BITs, for sustainable investment which is a highly topical issue of the contemporary international investment law. ${ }^{41}$

Third, in order to strengthen the regulatory power in the financial service sector, both the China-Canada BIT and the CJK TIT provide carve-outs for prudential measures. The China-Canada BIT contains a general exceptions clause in which States' measures are defended for prudential reasons including the protection of depositors, financial market participants and investors, policyholders, policy-claimants; the maintenance of the safety, soundness, integrity or financial responsibility of financial institutions; and the preservation of the integrity and stability of a contracting party's financial system. ${ }^{42}$ When comparing with the China-Canada BIT, the CJK TIT covers fewer aspects including investors, depositors, policy holders, the integrity and stability of the financial system. ${ }^{43}$ It is noteworthy that the prudential measures in the CJK TIT do not address financial institution-related issues (e.g., safety, soundness, integrity and responsibility). Instead, both the China-Canada BIT and the CJK TIT cover financial system. In this regard, States' measures to protect individual financial institution are not likely to be defended by the CJK TIT and States' regulatory space is thus narrower in the treaty. 
Table 3: C4 Prudential Measures in the Financial Sector

\begin{tabular}{|c|c|}
\hline China-Canada BIT 2012 & CJK TIT \\
\hline \multicolumn{2}{|c|}{ depositors } \\
\hline \multicolumn{2}{|l|}{ financial market participants } \\
\hline \multicolumn{2}{|l|}{ investors } \\
\hline \multicolumn{2}{|c|}{ policy holders } \\
\hline \multicolumn{2}{|l|}{ policy-claimants } \\
\hline $\begin{array}{l}\text { persons to whom a fiduciary duty is owed } \\
\text { by a financial institution }\end{array}$ & $\begin{array}{l}\text { persons to whom a fiduciary duty is owed } \\
\text { by an enterprise supplying financial services }\end{array}$ \\
\hline \multicolumn{2}{|l|}{ safety of financial institutions } \\
\hline \multicolumn{2}{|l|}{ soundness of financial institutions } \\
\hline \multicolumn{2}{|l|}{ integrity of financial institutions } \\
\hline \multicolumn{2}{|l|}{$\begin{array}{l}\text { financial responsibility of financial institu- } \\
\text { tions }\end{array}$} \\
\hline \multicolumn{2}{|c|}{ integrity of financial system } \\
\hline stability of fi & nancial system \\
\hline
\end{tabular}

Fourth, regulatory power of the host countries is embodied through the exceptions to the free-transfer-of-funds obligation. Under Article 19 of Temporary Safeguard Measures, the CJK TIT entitles the host countries to adopt or maintain measures not conforming the obligations of transfer and the national treatment regarding transnational capital transaction among these three countries. It can be enforced under the circumstances of serious balance-of-payments difficulties/threat, serious external financial difficulties/threat and serious macroeconomic management difficulties/threat in exceptional situation. ${ }^{44}$ The China-Canada BIT also stipulates that a contracting party can restrict transfers in the situation of serious balance of payment difficulties/threat. ${ }^{45}$ The China-Canada BIT provides exceptions to transfer under the provision of 'transfer,' while the CJK TIT included the exceptions in both the 'transfer' and "temporary safeguard measures" provisions. Moreover, the CJK TIT presents more options for the host states to limit or prevent free transfer in the circumstances of serious external financial and macroeconomic management difficulties or threat, which was not invoked by the China-Canada BIT. 
Table 4: C5 Regulatory Power to Limit/Prevent Transfer

\begin{tabular}{l|l}
\hline \multicolumn{1}{c|}{ China-Canada BIT 2012 } & \multicolumn{1}{c}{ CJK TIT 2012} \\
\hline Prevent transfer & Delay or prevent transfer \\
\hline \multicolumn{1}{c}{ bankruptcy } \\
\hline insolvency
\end{tabular}

\section{The FPS OF THE 18TH PCC}

The National Congress of the Communist Party of China ("NCCPC"), which started in 1921, runs once every five-years. The NCCPCs discusses every aspect of national agenda including the election of CPC leaders, socio-economic development, and domestic and foreign policy. The Plenary Session ("PS") is organized by the Party Central Committee ("PCC") at least once a year, in which the leadership of governmental organs, the general direction of social and economic evolution, the 
adjustment of national policies and international strategy are discussed. ${ }^{46}$

The FPS of the 18th PCC, held in October 2014, was a watershed as it was the first FPS in China to discuss the issues of "regulating a country by law," "47 which would influence China of strategic significance.

\section{A. The FPSs}

Since the first NCCPC of 1956, China has organized 10 NCCPCs. Generally, each PCC organized 7 PSs within every five-years. ${ }^{48}$ The main agenda of the first PS includes the election of the members of the Political Bureau of the Central Committee; the second PS focuses on the preparation for the personnel change of the State Council, National People's Congress, Supreme Court and Supreme Procuratorate and the seventh PS prepares for the next PCC. ${ }^{49}$ The other three PSs usually have different focuses including economy, agriculture, the Party construction and the reform of the administrative system. The 4th PS (FPS) connects the agendas which have been and will be implemented. The FPS is therefore regarded as a 'key PS. ${ }^{, 50}$ Table 5 demonstrates the core agendas of certain FPSs. It illustrates that three out of the four latest FPSs examined the constructions of the Party, which constituted a standing issue for each FPS. However, the 2014 FPS conferred legal construction, which was therefore considered as an evolutionary FPS.

\section{B. The FPS of the 18th PCC in 2014}

Since 2013 China has been deepening the reforms in a comprehensive way, which was initiated at the Third PS of the 18th PCC as a benchmark of the country. For the 'deep' and 'comprehensive' reforms, China has been in a period seeking changes including the law. The FPS of the 18th PCC in 2014 discussed legal affairs. 
Table 5: The Main Agenda of the FPSs in most recent 11 PCCs

\begin{tabular}{c|l}
\hline PCC & \multicolumn{1}{c}{ Main Agenda } \\
\hline $8^{\text {th }}$ PCC & Candidates of the presidium \\
\hline $11^{\text {th }}$ PCC & PCC Decision on Certain Issues Promoting Agriculture Development \\
\hline $12^{\text {th }}$ PCC & $\begin{array}{l}\text { Mechanisms facilitating new leaderships for central organs; PCC Suggestions } \\
\text { on the Seventh Five-Year Plan for the Development of National Economy } \\
\text { and Society }\end{array}$ \\
\hline $13^{\text {th }}$ PCC & Adjustments to the personnel of the PCC \\
\hline $14^{\text {th }}$ PCC & $\begin{array}{l}\text { PCC Decision on Several Significant Issues Regarding the Construction of } \\
\text { the Party }\end{array}$ \\
\hline $15^{\text {th }}$ PCC & $\begin{array}{l}\text { PCC Decision on Several Significant Issues regarding the Reform and } \\
\text { Development of State-Owned Enterprises }\end{array}$ \\
\hline $16^{\text {th }}$ PCC & PCC Decision on the strengthening of the Party's Administrative Ability \\
\hline $17^{\text {th }}$ PCC & $\begin{array}{l}\text { PCC Decision on Several Significant Issues regarding the Strengthening and } \\
\text { the Improvement of the Party's Construction under the new circumstances }\end{array}$ \\
\hline $18^{\text {th }}$ PCC & PCC Decision on the construction of the Rule of Law \\
\hline
\end{tabular}

Source: Review of the Fourth Plenary Session after the Foundation of the PRC, China Law Society Website (21 October 2014) available at http://www.chinalaw.org.cn/Column/Column View.aspx?ColumnID=929\&InfoID=10355 (last visited on Dec. 8, 2014).

Some elements facilitated the law-themed FPS of the 18th PCC. First, the economic restructure in China's transition calls for "economic growth in pursuant to law" from the merely "economic growth." ${ }^{51}$ The current legal system is thus required to be reviewed and rectified for the economic transition from the perspectives of internal judicial management system, judicial power operation mechanism, and judicial power supervision mechanism. ${ }^{52}$ Second, social problems such as social contradictions, corruption, and the gap between the rich and the poor are emerging significantly in the transition, which would amount to the obstacle of the "Comprehensive Well-off Society" target in 2020. A comprehensive legal system is hence needed to diminish these obstacles through regulating social behaviors, balancing social interests and solving social problems. In order to achieve the targets by 2020, deeper and more comprehensive reforms in the next six years have to be finished efficiently and legitimately. 
Against this backdrop, the FPS of the 18th PCC passed the "PCC Decision on Certain Significant Issues Regarding the Promoting the Governance of the Country by Law" (hereafter PCC Decision). ${ }^{54}$ The PCC Decision augmented the protection of private rights and property, provoking the people's devotion to the social and economic reforms. Furthermore, the PCC Decision indicated that foreign investors would gain more judicial resources in China, demonstrating an open and flexible environment for foreign investments. Finally, the PCC Decision is consistent with the sustainable economic and social development by providing transparent judicial impartiality and strengthened governmental public trust. ${ }^{55}$

\section{The PCC Decision}

The PCC Decision contains extensive provisions to facilitate China's philosophy of "governing the country by law" from the perspectives of construction and revolution of constitutional law, administrative law, judicial system, social legal awareness and legal professionals. ${ }^{56}$

With regard to the constitutional constructions, the PCC Decision established the National Constitutional Day on December 4 and set requirements for "scientific and democratic" legislations in the imperative fields including fair economic market, investment management, energy utilization, environmental protection, national security, etc. The aim of protecting private property rights is to encourage the devotion to social reform. Filling legal gaps would strengthen the orderliness in certain sectors which is a constitutional ground.

The purposes of constructing administrative legal system are to: (1) fulfill government duty comprehensively; (2) improve administrative decisionmaking mechanism through introducing government-counsels and lifelongresponsibility; (3) deepen the reforms of administrative execution through integrating resources and improving efficiency; (4) strengthen the civilization in administrative execution; (5) enhance the supervision of administrative power; and (6) promote the transparency and publicity of the overall administrative affairs. ${ }^{57}$ These indicated China's determination to purify the administrative execution environment and to prevent corruption, ${ }^{58}$ which further facilitates the economic and social reforms.

When it comes to the construction of the judicial system, China commits to establishing the circuit by the Supreme Court to settle the cross-district disputes. ${ }^{59}$ 
The cross-district People's Court and People's Procuratorate are expected to make judgements over the cross-boards cases, which constitutes an experimental attempt in the judicial reforms. ${ }^{60}$ The circuit and the cross-district courts will be the first endeavor in the history of China's judicial reforms. It demonstrates the country's intention not to interfere into the district question. ${ }^{61}$ Further transparency will then be added into the judicial system, which reflects the requirement of "governing the country by law" of the 18th PCC.

Promoting people's legal awareness requires higher education to adjust Chinese tradition of 'avoiding litigation. ${ }^{62}$ The construction of legal professionals includes the training of researchers and practitioners tackling rules and regulations for international dispute settlement. ${ }^{63}$ Complying with the principle of "governing the country by law," both are expected the countrywide dissemination of law for the target of 2020 .

\section{The INTERPLAY OF THE PCC DeCISION WITH THE INTERNATIONAL INVESTMENT TreATIES IN ChinA}

Among all the Party's documentations and policies, the decisions reached by the PCC are the most influential and significant instruments that can bring farreaching changes to the country. The third PS of the 11th PCC, e.g., initiated the "Open-up and Reform" decision, which profoundly influenced the society, politics, economy, culture and diplomacy of the nation. ${ }^{64}$ The PCC Decision and the future legal reforms will thus improve the stability and transparency of the legal environment for foreign investment in China. The Chinese BITs practice and the tribunals' arbitration practice will inevitably be influenced by the legal reforms. They would have relevance to the arrangements of treaty provisions, the number of investment disputes before international tribunals, and the local remedies for international investors.

\section{A. Augmenting Investment Disputes before International Tribunals}

So far, very limited number of investment dispute cases concerning China or Chinese investors were claimed under international tribunals. It is mainly due to the Chinese legal tradition of 'avoiding litigation' and the lack of professionals. 
However, these would no longer be obstacles with the PCC Decision.

The PCC Decision addressed that the principle of "governing the country by law" should be promoted nationwide, aiming that all the Chinese people will advocate, comply with, and defend law. In case of disputes between foreign investors and the Chinese partners, the Chinese parties are more likely to resort to legal mechanism. Also, the governmental bodies are gradually required to deal with the investment disputes with foreigners by law only. In addition, a set of comprehensive legal mechanisms have been stipulated to facilitate the settlement of dispute. The PCC Decision provided the comprehensive mechanism to promote the publicity of governmental affairs. With the Decision, foreign investors can get more access to the administrative authorities, administrative procedure, the supervision body and the applied laws which could be invoked as critical evidence before international tribunals. $^{65}$

The lack of professionals in the field of international investment law is partially due to the defects of the legal education system in China ${ }^{66}$ including the "ossified textbook-based teaching,"67 "decreased quality of legal education,",68 and "ambiguous purpose of legal education." 69 However, it is expected to be improved because the PCC Decision has required the training and establishment of professional teams including judges, procurators, notaries, practitioners and scholars in order to deal with international cases more efficiently. Without enough professionals of international investment law, the host country tried to resolve such disputes by means of compromise or other private mechanisms. Although the professionals-team does not constitute a decisive element for the host country and international investors to bring disputes to international tribunals, the improved legal professionals will undoubtedly increase the possibility of international dispute settlement.

\section{B. Fertilizing the Content of 'Host State Law' in Investment Treaties}

The FPS of the 18th PCC and the legal reforms thereof will alter the content of Chinese BITs and the obligations of foreign investors substantively through the treaty provision requiring investors to comply with the host countries' laws. The provision constitutes one mechanism to defend the host countries against treaty claims. It is laid down in a number of investment treaties. If a treaty provides that "each contacting party shall admit investments in accordance with its laws and 
regulations," it can be commonly found in all the three stages of Chinese BITs above. ${ }^{70}$ Such a provision incorporates foreign investors' obligations into the promotion and protection of their investments. It also provides a "weapon for host states to defeat investment treaty claims in appropriate circumstances.",

However, whether foreign investors should comply with the "investor legality provision" 72 depends on the scope of host countries' laws because the wording of each provision links directly to their legislations. Although the PCC Decision did not provide for details regarding the legislative reforms, nor did it contain the deadline for the reforms, it did introduce compulsory guidelines to adjust the current legislations. As mentioned above, because the pre-2014 PCC did not discuss legal questions, the PCC Decision is expected to promote the legal reforms significantly in China. ${ }^{73}$ In this regard, the PCC Decision and the possible changes to the legal system have the potential to trigger questions on the scope and content of investors' obligations under the new legislations in the future.

\section{Improving the Legislative System}

The legislation reforms are contained in the section of constitutional construction in the PCC Decision, providing a general direction the future legislations may follow. It is noteworthy that the PCC Decision did not introduce comprehensive guidelines particularly for international investment. Therefore, the definite interaction between the PCC Decision and Chinese investment treaties will be reflected through the reformed laws and system eventually. Theoretically, the binding provisions of investment treaty may conflict with the amended laws, which might require the termination of treaty provisions in question. Legislative reforms shall be introduced by positive system of lawmaking. ${ }^{74}$

The legislative system reforms comprise three main aspects. First, the drafting of the comprehensive and fundamental laws will be initiated by the Commission of Legislative Affairs of the Standing Commission of National People's Congress. Second, the important laws and regulations of administrative affairs will be drafted by governmental bodies dealing with legal affairs. Third, the boundaries of legislative power among different bodies will be outlined more precisely to diminish local protectionism ${ }^{75}$ and the independent third party will be introduced to facilitate the settlement of legislative disputes among the bodies above.

The proposed legislative reforms are expected to provide a more transparent 
investment environment for foreign investors although the stability might be weakened because of the ongoing changes. ${ }^{76}$ E.g., the strengthened participation of people and third party in legislative reforms proposed by the PCC Decision would facilitate the access to legislations with the discussion and drafting and to release and announcement of laws. As transparency is usually provided in the fair and equitable standard in investment treaties, the legislative reforms not only respond the economic transition in China but comply with investment treaty requirements. ${ }^{77}$

\section{Drafting and Amending Laws}

The PCC Decision proposed drafting laws in the areas where there is no law and amending laws where the current laws need to be improved significantly in order to conserve the private rights (including private investors). The PCC has acknowledged that the current Chinese legislation has defects. ${ }^{78}$ Certain laws were enacted in the early Open-up period, but they are no longer sufficient to cope with the emerging disputes. ${ }^{79}$ Some laws are indistinct and obscure judicial practice while others are containing the interests of certain government bodies. ${ }^{80}$ It is thus implied that not only new laws are to be enacted, but also the old laws will be amended, otherwise the economic and social transition would face obstacles.

First, property laws should be improved for an equitable market. The laws and regulations lacking 'equity' will be abrogated in order to protect "the property rights of natural person and economic organizations of all forms of ownerships." Accordingly, private property rights including those of foreign investors would be respected more by the reformed legislations. The protection of the property under State and collective-ownership will be enhanced, as well. ${ }^{82}$ It may indicate that the private participants nevertheless would not possess the competitive advantages in the State and collective-ownership dominated sectors. Whether the strengthened equity for private property rights proposed by the PCC Decision is sufficient for private participants in the transition is thus unknown because the proposal takes time to be translated into laws, regulations or rules.

Second, in the area of market legislative constructions, the PCC Decision proposed the compiling of the Civil Code of China and the supporting laws and regulations covering the areas of investment management, land management, energy and mineral resources, agricultural, revenue tax and finance. ${ }^{83}$ Obviously, 
these proposals are related to the rule of law in economic activities. The PCC Decision, however, did not ignore non-economic aspects. E.g., it proposed establishing laws promoting cultural industry in the sector of cultural service, laws of national honor, laws of internet security, service and management, laws in public service sectors including education, employment, income allocation, social welfare, public medicine, food safety, charity, social aid, the protection of women, the old, the disabled, as well as the environment. ${ }^{84}$ Those legislative reforms in the non-economic areas are comprehensive for supporting the economic transition better. In this regard, the proposed legislative reforms seem to be driven mainly by the transition in China, which aimed to achieving the two 100 -year goals ${ }^{85}$ in the coming years. The goals above in turn require both economic and non-economic reforms because the later can help eliminate the difficulties in social welfare, income allocation, poverty, environment, etc. ${ }^{86}$

The PCC Decision stressed legislative reforms for environmental protection. More focuses are on the strengthening the legal responsibility and boosting the cost significantly for pollution. The PCC Decision suggests that if foreign investors fail to comply with the reformed environmental laws and regulations, they would be punished more strictly. However, problems would still exist even when the reforms are completed because most of investment treaties concluded by China do not include environmental provisions. International tribunals then are not obliged to consider environmental issues in treaty interpretation, which prevents the stricter environmental laws under the domestic legislative reforms.

As a result, the current investment treaties need to be reformed as well in order to cater for the legislative reforms in China on the one hand, and the noninvestment considerations which are receiving increasing attention on the other. ${ }^{87}$ However, this process will be tough because of the re-negotiations with countries of different development stages.

Third, the PCC Decision has proposed the legislative constructions on national security under the comprehensive rule of law. The National Security Committee ("NSC") was finally established on January 24, 2014 at the meeting of the Party Central Political Bureau. ${ }^{88}$ The NSC is responsible for the Party Central Political Bureau and the Standing Committee thereof with regard to the essential issues concerning national security. ${ }^{89}$ In the context of the PCC Decision, the NSC should also be integrated into the legal framework and the legislations on national 
security issues will grant the NSC legal powers.

'National security' is an issue in international investment regime because it is used to justify States' behaviors in certain investment treaties. In such cases as Ralls Corporation v. Committee on Foreign Investment in the United States ${ }^{90}$ and the CNOOC-Unocal Transaction, ${ }^{91}$ Chinese investors such as Huawei and ZET have been rejected out of the American investment market completely for security reasons. ${ }^{92}$ Considering the US and Russia have established national security council or similar organizations, the NSC can reasonably check foreign investment.

However, a question may arise whether the NSC and the legislations will impose substantive influence on foreign investment in a short term. On the one hand, the NSC was just formed in early 2014 so that the laws, regulations and rules regarding the national security issues need to be discussed, drafted and amended on the basis of the current NSC practices. On the other hand, the NSC focuses on providing a stable environment internally and externally to support the current transition. The legislations thereof are likely to stress how to diminish public security threats caused by terrorists ${ }^{93}$ instead of foreign investors. There is a possibility for the NSC to intervene into investment-related security issues because the Committee is entitled to "make policies with regard to national security" and the Exposure Draft of the Foreign Investment Law of the PRC has added 'national security' into the scrutiny of foreign investment. ${ }^{95}$ Before taking an action, however, the NSC should take lessons from the Chinese cases before the US courts.

The PCC Decision requires not only enacting new laws to fill the legislative gaps in certain fields, but also improving the existing legislations. Regardless of enacting new laws or improving the current laws, the PCC Decision is expected to shape the future legislative reforms in China, which will undeniably fertilize the scope and content of China's domestic laws and regulations. As legal reforms in the specific areas are going on, foreign investors should pay attention to them before setting up investment projects in China because those reforms will have a great influence on their investment.

As mentioned above, China began to seek balance between investors and the host countries adopting more regulatory provisions in investment treaties. The PCC Decision and the following domestic laws will further enhance and clarify 
the content of States' regulatory power. As a consequence, the domestic legislative reforms should commonly go together with the new investment treaties.

\section{Improving Judicial Remedies for International Investors}

With regard to the proposed reforms of judicial system, the PCC Decision introduced new mechanisms. First, the PCC Decision suggested the separation of judicial and administrative functions of the courts. It implies the complete independence of the court from administrative and executive affairs.

Second, the PCC Decision called for establishing the circuit court and the cross-administrative-regions courts. The new forms of courts are expected to improve the independent and impartial line of jurisdiction between the central and local courts; they will facilitate people to access the court. ${ }^{96}$ These would comply with the PCC Decision for impartial and credible court. ${ }^{97}$ Moreover, foreign investors in China will also benefit from the potentially improved judicial resources.

Among the 146 BITs concluded by China, more than 60 percent were signed before 1998. These BITs generally included narrow scope of investment dispute provisions, allowing only the disputes concerning the compensation for expropriation to be brought to international arbitration. ${ }^{98}$ As only less than 20 percent of those BITs have been replaced by new BITs with broader dispute settlement provisions, the remaining majority BITs still limit foreign investors to access to international arbitration when disputes occur. The domestic dispute settlement mechanisms in China therefore constitute an inevitable form of remedy for foreign investors. ${ }^{99}$ When disputes arise out of the non-expropriation issues, international settlement mechanisms are not available under these BITs. In this case, the alternative solutions can be reached through investment contracts or other agreements. As of today, the local remedies including litigation and arbitration are still feasible in China for the investment disputes. The proposed judicial reforms by the PCC Decision are thus expected to benefit the foreign investors in the future.

The PCC Decision and the proposed judiciary reforms have the potential to reintroduce the "access to justice" principle with new investment treaties. "Access to justice" is an international custom, providing local remedies pursuant to the laws of the host countries. ${ }^{100}$ The majority of the BITs concluded by China do 
not contain a provision requiring the exhaustion of local remedies. Although some Chinese BITs provide it as a compulsory requirement when the duration of the exhausted procedure may differ. The China-Columbia BIT (2008) demands the exhaustion of domestic settlements according to the host State law before sorting to the investor-state dispute settlement. ${ }^{101}$ The BIT between China and the Belgium-Luxembourg Economic Union has prescribed the exhaustion of local remedies from the Chinese perspective. Here, the procedure was further limited into a shorter three month time instead of six months as laid down at the ChinaColumbia BIT. ${ }^{102}$ The practice of the China-Belgium-Luxembourg BIT can be found in the China-Latvia BIT (2004), China-Netherlands BIT (2001) and ChinaTunisia BIT (2004), ${ }^{103}$ as well. Such investment instruments are identical because exhaustion is asked as 'compulsory' by China. In another group of Chinese BITs, exhaustion of local remedies is an optional choice by adopting the terms of "may require exhausting the domestic procedure." Noticeable examples are: ChinaDjibouti BIT (2003), China-Guyana BIT (2003), China-India BIT (2006), ChinaMyanmar BIT (2001), and China-Trinidad and Tobago BIT (2002). ${ }^{104}$ The ChinaFinland BIT (2004) also provides for an optional exhaustion of local remedies. It confines the scope of the remedies within China, instead of both contracting parties. $^{105}$

Although many investment treaties are circumventing the exhaustion of remedies principle before international arbitration ${ }^{106}$ in order to enhance the efficiency and impartiality of international dispute settlement, ${ }^{107}$ the treaty and arbitral practice indeed entitle investors from developed countries to avoid the judicial settlement in developing countries. ${ }^{108}$ Since the current treaties and arbitral practices have substantially surrender the judicial power of developing countries to international arbitration and do not achieve the reciprocity between developed and developing countries, ${ }^{109}$ the internal law and judicial settlement of the host countries are advocated to return back into investment treaties and proposed to have a solid control over international investment disputes. ${ }^{110}$ Both investment arbitrators and scholars have addressed that the local remedies of developed countries are required to be exhausted while those of the developing countries give way to protecting foreign investment. ${ }^{111}$ In order to preserve the judicial space of the host states, the domestic remedies in investment treaties, ${ }^{112}$ addressed by the EU in 2011, ${ }^{113}$ would be suggested. E.g., the Transatlantic Trade and Investment 
Partnership ("TTIP") has illustrated the EU members' explicit position to overstep the international dispute settlement. ${ }^{114}$ As regard the investor-state dispute settlement ("ISDS") mechanism in the EU-US TTIP, the Union's Incoming Commission head, Jean-Claude Juncker noted that: "Under no circumstances would the ISDS have the final say over any dispute that could arise between companies and governments and the rule of law and the principle of equality before the law would prevail. ${ }^{, 115}$ He has also indicated that the ISDS may not be a part of the TTIP. In this context, EU investment treaties would return to the local remedies principle on the ground that the domestic laws of the EU member States are able to grant foreign investors sufficient protection. ${ }^{116}$

New generation of investment treaties calls for the balance of interests between private investors and the host countries, as well as between the international and domestic settlements. In this sense, the EU's reintroducing local remedy principle would provide illustrative implications. If the exhaustion principle are added into investment treaties, the efficiency of the host countries' laws and judicial remedy would be required, as has been repeatedly elaborated by the EU members ${ }^{117}$ and international tribunals. ${ }^{118}$ Eventually, the PCC Decision and the proposed judicial transformation in China may improve the efficiency, transparency and equality for the protection of investors. The circumstances are therefore likely to facilitate the internal judiciary control over investment disputes and to equally allocate judicial powers between international and national settlements, which eventually contribute to the balance between foreign investors and China, the host country.

\section{Conclusion}

Comprehensive legal reforms have been called for by the Chinese society, especially in this period of economic and social transition. The historical FPS of the 18th PCC in 2014 addressed the legal constructions and transformations comprehensively in the hierarchical form of a Party documentation. This PCC Decision has provided benchmark and general guidelines for legal reforms in China. Based on the PCC Decision, the Cross-Administrative-District Court was established and the Exposure Draft of the Foreign Investment Law of the PRC was released, which are unprecedented in China. 
This paper has explored the influence of the legal reforms to international investment practices in China focusing on the FPS of the 18th PCC. The author has tried to expose the development of Chinese BITs practice, especially after 2012 which demonstrates the trend towards the balance between private investors and the host countries. It is illustrated that China's BIT practices have experienced the "cautious investment protection" and "expanded investment protection," and are now experiencing the "balanced investment protection." The post-2012 Chinese BITs increasingly began to accommodate non-investment interests of the host countries.

In order to explore the links between the latest legal reforms in China and the new development of Chinese BITs, the author has evaluated the PCC Decision and the legal transformations including constitutional law, administrative legal system, judicial system, people's legal awareness and legal professionals. The PCC Decision has proposed the principle of "governing the country by law" nationwide, which functions differently from the legal tradition of 'hating litigation' in China. It will encourage the settlement of investment disputes through judicial manner including international arbitration. The PCC Decision has suggested amending and enacting laws, which will fertilize the content of "host state law." Such legal reforms will eventually lead foreign investors to comply with investment treaty provisions with China. The more comprehensive host state laws are, the more effectively balance is reserved in international investment treaties.

Considering the judicial remedies of the host countries especially within the EU investment treaties, the international community should enhance the States' regulatory power through different treaty provisions. Whether the balance between international and domestic judicial powers over investment disputes can be achieved in treaty practice is not fully confirmed. However, efficient and transparent judiciary should be referred to as a pre-condition. The separation of jurisdiction and execution within the court, the establishment of circuit court by the Supreme Court and the establishment of the cross-administrative-regions courts were all introduced by the PCC Decision in order to strengthen the availability, efficiency and transparency of the legal system in China.

Investment treaties do not yet deal with private investors and the host countries in a balanced manner. In addition, investment disputes are not impartially tried by international and domestic court. However, the recent development of Chinese 
BITs are adjusting such imbalances with more provisions for the host countries. The continuous calling for legal reforms in China and the current proposal from the PCC Decision not only provide opportunities for foreign investors to resolve disputes through international judicial mechanism, but also potentially retain greater capacity for domestic judiciary over international investment disputes.

\section{REFERENCES}

1. Karl Sauvant and Lisa Sachs investigated in the literature reflecting the relations between BITs and investment flow, finding that BITs have strong effect, weak effect, no effect or even negative effect on international investment flows according to different researches. See K. Sauvant \& L. Sachs, The Effect of Treaties on Foreign Direct Investment: Bilateral Investment Treaties, Double Taxation Treaties, and Investment Flows 254-71 (2009).

2. UnCtad, The Role of International Investment Agreements in Attracting Foreign Direct Investment to Developing Countries 112 (2009), available at http://unctad.org/en/ Docs/diaeia20095_en.pdf (last visited on Feb. 8, 2016).

3. The first ICSID arbitration under a China BIT is Tza Yap Shum v. Republic of Peru, ICSID Case No. ARB/07/6), which awarded USD 786,000 compensation to Mr. Tza in 2011. The second ICSID arbitration under a China BIT is Ping An Life Insurance Company of China v. Kingdom of Belgium (ICSID Case No. ARB/12/29). The first case regarding a claim against China at ICSID is Ekran Berhad v. People's Republic of China (ICSID Case No. ARB/11/15), which concerns a Malaysian construction investment project in China. A South Korean property investor became the second investor to request ICSID arbitration against China through Ansung Housing Co., Ltd. v. People's Republic of China (ICSID Case No. ARB/14/25), which concerns a development project for a golf country club and condominiums. The latest arbitration concerns Chinese investors in 2014 is Beijing Urban Construction Group Co. Ltd. v. Republic of Yemen (ICSID Case No. ARB/14/30), register on December 3, 2014 and the tribunal was constituted on July 10, 2015.

4. An Chen, Not to Dismantle the Four Safety Valves in Chinese BITs: Analysis of Dispute Settlement Provisions in Treaty Negotiation Based on the US and Canada Model BITs, 中外 双边投资协定中的四大“安全阀”不宜贸然拆除一美、加型 BITs 谈判范本关键性“争端解决”条款剖 析, 1 J. INT'L. ECON. L. 国际经济法学刊 26 (2006).

5. E.g., the General Exceptions provision in the China-Canada BIT (2012) widely included cultural industries, environmental issues, natural resources, and financial and monetary policies. Such treaty practice illustrates that the BIT has increased the scope of states' regulatory space when compared with the majority of the BITs concluded by China. See China-Canada BIT art. 33, pt. D. The China-Japan-Korea Trilateral Investment Treaty 
embraced the stand-alone provisions of 'security exceptions,' "temporary safeguard measures," and 'environmental measures,' through which the host states' security interests, financial interests and environmental interests were all preserved against the violation of treaty obligations. See China-Japan-Korea Trilateral Investment Treaty arts. 18, $19 \& 23$.

6. Wenke Li, Keqiang Li hopes to reach mutual balanced China-US BIT 页面没有找 到, Reuters News (Nov. 13, 2014), available at http://cn.reuters.com/art./chinaNews/ idCNKCS0IW2PC20141112 (last visited on Feb. 8, 2016).

7. See Fourth Plenary Session of the Eighteenth Party Central Committee of the PRC of 2014.

8. As of January 2016, 2280 out of 2923 BITs are in force, while other 358 international investment agreements exist. See UNCTAD Investment Policy Hub, available at http:// investmentpolicyhub.unctad.org/IIA (last visited on Jan. 31, 2016).

9. This is one of the reasons leading Venezuela, Bolivia and Ecuador to denounce the ICSID Convention. See S. Ripinsky, Venezuela's Withdrawal from ICSID: What It Does and Does Not Achieve, IISD Investment Treaty News, Apr. 13, 2012, available at http://www.iisd.org/ itn/2012/04/13/venezuelas-withdrawal-from-icsid-what-it-does-and-does-not-achieve (last visited on Feb. 16, 2016).

10. The terminated BITs are included here, but those BITs not in force.

11. The 19 instruments include 3 Framework Agreements, 10 Free Trade Agreements, 2 Partnership Agreements, 1 Trade and Cooperation Agreement, 1 China-ASEAN Investment Agreement, 1 APTA Investment, and 1 Trilateral Investment Agreement. For details, see UNCTAD Investment Policy Hub, available at http://investmentpolicyhub.unctad.org/IIA/ CountryOtherlias/42\#iiaInnerMenu (last visited on Feb. 8, 2016).

12. Miaojie Yu, Thirty Years of External Trade in China: 1978-2008, in ThirTy YeArs of Reform and Opening Up in China: Mutability and Immutability 80 (Weishuo Zheng \& Jinyi Luo eds., 2008).

13. M. Hwang \& N. Thio, Investment Treaty Arbitration in Asia: Contemporary Issues and Challenges, in Transnational Dispute Management 3 (2012), available at http://www. transnational-dispute-management.com/article.asp?key=1829 (last visited on Dec. 12, 2015).

14. Article 13 (Investment Disputes) of the China-Singapore BIT 1985 and Article 13 (Investment Disputes) of the China-New Zealand BIT 1988 stipulated that: "If a dispute involving the amount of compensation resulting from expropriation... it may be submitted to an international arbitral tribunal established by both parties."

15. Such phenomenon is known as 'Yan Su 庈诉' in Chinese legal history. See Xiaolong Hou, Legal Basis and Factors Leading to Yan Su, 3 J. Citizen High Edu. Res. 26 (2011).

16. N. Eliasson, Investor-State Arbitration and Chinese Investors - Recent Developments in Light of the Decision on Jurisdiction in the Case Mr. Tza Yap Shum v. The Republic of Peru, 2 Contemp. Asia ARb. J. 347-53 (2009).

17. Yu Xiao \& Jiao Lei, Overview of the Strategy of Going Global “走出去” 战略概述, 2 QIAO 
Wu Gong Zuo Yan JIU 侨务工作研究, the official website of Overseas Chinese Affairs Office of the State Council (2011), available at http://qwgzyj.gqb.gov.cn/yjytt/159/1743. shtml (last visited on Feb. 8, 2016).

18. Canrong Jin, Review of the Going Global Policy: Achievements and Challenges 走出去战略 回顾: 成就与挑战, 8 MODERN INT'L REL. 现代国际关系2 (2011).

19. The Tenth Five-Year Plan for National Economic and Social Development of the PRC 20012005 中华人民共和国国民经济和社会发展. 第十二个五年规划纲要

20. On the basis of the Opening-up Policy, the Eleventh Five-Year Plan for National Economic and Social Development of the PRC 2006-2010 adopted the international cooperation and competition policy in a "wider scope, broader area and higher level." The Further Going Global Policy in this period encouraged Chinese investors to invest in infrastructure with a high ratio of state owned capital. See Premier of the State Council in China, Government Work Report of the PRC: Instruction on the Draft of the Eleventh Five-Year Plan for National Economic and Social Development 中华人民共和国国民经济和社会发展第十一个五 年规划纲要 (Mar. 5, 2006), available at http://www.gov.cn/ztzl/gmjj (last visited on Jan. 31, 2016).

21. "Fasten the implementation of going global," coupled with "optimize the structure of external trade," "improve the utilization of foreign capital" and "positively participate in the global economic governance and regional cooperation," constitute the four requirements to improve the level of opening up during the 12th five year plan. See Jiabao Wen, Instruction Regarding the Institution of the Twelfth Five-Year Plan for National Economic and Social Development 关于制定国民经济和社会发展第十二个五年规划建议的说明, 21 QIU SHI 求是 23 (2010).

22. An Chen \& Congyan Cai, New Development of International Investment Law and New Practice OF ChINESE BITs 国际投资法的新发展与中国双边投资条约的新实践 440 (Fudan U. Press, 2007).

23. A. Berger, China's New Bilateral Investment Treaty Program: Substance, Rational and Implications for International Investment Law Making, paper prepared for American Society of International Economic Law Interest Group biannual conference (Nov. 14, 2008), available at http://www.die-gdi.de/uploads/media/Berger_ChineseBITs.pdf (last visited on Feb. 8, 2016).

24. For the statistics, see PRC Ministry of Commerce, Bilateral Investment Treaty 我国对外签订 双边投资协定一览表 (Nov. 8, 2011), available at http://tfs.mofcom.gov.cn/article/Nocatego ry/201111/20111107819474.shtml; China-Bilateral Investment Treaties, UNCTAD Investment Policy Hub, http://investmentpolicyhub.unctad.org/IIA/CountryBits/42\#iiaInnerMenu (all last visited on Feb. 8, 2016).

25. China-Germany BIT 2003 art. 13. It reads: "Either Contracting Party may propose to the other Contracting Party that consultations be held on any matter concerning interpretation, application and implementation of the Agreement. The other Contracting Party shall ... 
shall afford adequate opportunity for such consultations."

26. T. Shenkin, Trade-Related Investment Measures in Bilateral Investment Treaties and the GATT: Moving Toward a Multilateral Investment Treaty, 55 U. PitT. L. Rev. 559-60 (1994).

27. Id. art. 2.

28. Id. art. 4.

29. Id.

30. China-Germany BIT 2003 art. 9 (Settlement of Disputes between Investors and one Contracting Party).

31. Id. art. 9 .

32. K. Davies, Inward FDI in China and Its Policy Context, Columbia University Academic Commons (Oct. 24, 2012), available at http://academiccommons.columbia.edu/catalog/ ac:154497 (last visited on Feb. 8,2016).

33. L. Cheng \& Zihui Ma, China's Outward FDI: Past and Future, in China's Growing Role IN World Trade 547-49 (R. Feenstra \& Shang-Jin Wei eds., 2010).

34. FDI outflow from China, Hong Kong and Macau accounts for $6 \%$ of global FDI stock. See OECD International Direct Investment Statistics 2014 (as of June 30, 2014), available at http://dx.doi.org/10.1787/idis-2014-en (last visited on Feb. 11, 2016).

35. CJK TIT Security Exceptions art. 18. It reads: "1. ... each Contracting Party may take any measure: (a) which it considers necessary for the protection of its essential security interests; (b) in pursuance of its obligations under the United Nations Charter for the maintenance of international peace and security."

36. China-Canada BIT 2012 Expropriation art. 10. It reads: "Covered investments or returns of investors of either Contracting Party shall not be expropriated ..., except for a public purpose, under domestic due procedures of law, in a nondiscriminatory manner and against compensation."

37. They are common in investment treaties: investments or returns of investors shall not be expropriated except for a public purpose, under domestic due procedures of law, in a nondiscriminatory manner and against compensation.

38. China-Canada BIT 2012 art. 8 (Exceptions). It reads: "1. Article 5 does not apply to: (a) treatment by a Contracting Party pursuant to any existing or future bilateral or multilateral agreement: (i) establishing, strengthening or expanding a free trade area or customs union; or (ii) relating to aviation, fisheries, or maritime matters including salvage."

39. Id. 5. Articles 5, 6 and 7 do not apply to: (a) procurement by a Contracting Party; (b) subsidies or grants provided by a Contracting Party, including government-supported loans, guarantees and insurance.

40. Id. art. 33 (General Exceptions). It reads: "2. Provided that such measures are not applied in an arbitrary or unjustifiable manner, or do not constitute a disguised restriction ..., nothing in this Agreement shall be construed to prevent a Contracting Party from adopting or maintaining measures, ... (b) necessary to protect human, animal or plant life or health; or 
(c) relating to the conservation of living or non-living exhaustible natural resources if such measures are made effective in conjunction with restrictions on domestic production or consumption."

41. 2014 World Investment Forum was themed "investing in sustainable development."

42. China-Canada BIT 2012 art. 33 (General Exceptions 3). It reads: "nothing in this Agreement shall be construed to prevent a Contracting Party from adopting or maintaining reasonable measures for prudential reasons, such as: (a) the protection of depositors, financial market participants and investors, policy holders, policy-claimants, or persons to whom a fiduciary duty is owed by a financial institution; (b) the maintenance of the safety, soundness, integrity or financial responsibility of financial institutions; and (c) ensuring the integrity and stability of a Contracting Party's financial system."

43. CJK TIT 2012 art. 20 (Prudential Measures). It reads: "1. Notwithstanding any other provisions of this Agreement, a Contracting Party shall not be prevented from taking measures relating to financial services for prudential reasons ..."

44. Id. art. 19. 1. It reads: "A Contracting Party may adopt or maintain measures not conforming with its obligations under Article 3 relating to cross-border capital transactions." Article 13 reads: “... (a) in the event of serious balance-of-payments and external financial difficulties or threat thereof; or (b) in cases where, in exceptional circumstances, movements of capital cause or threaten to cause serious difficulties for macroeconomic management, in particular, monetary and exchange rate policies."

45. China-Canada BIT 2012 art. 12.4. It reads: "Nothing in the Agreement shall be construed to prevent a Contracting Party from adopting or maintaining measures that restrict transfers when the Contracting Party experiences serious balance of payment difficulties, or the threat thereof ..."

46. Jing Kong, From the First to the Eighteenth National Congresses of the Communist PARTY OF China 从一大到十八大 27 (China Yan Shi Press, 2014).

47. The concept is called 'Yi Fa Zhi Guo 依法治国' in China, the wordings of which stand for ruling by law.

48. Zhongjie Li, Promoting the Research on the History of the Congress of Party Representatives 加强对党代会历史的研究, 5 ZHONG GUO DANG SHI YAN JIU中共党史研究 6-10 (2006).

49. Angang Hu, The Four Significant Decisions on Reforms in China 中国的四次重大改革决策, 5 Party ANd GOVERnMENT Forum党政论坛 33 (2014).

50. Yan Li, The Themes of the Fourth Plenary Sessions of the PCC after the Reform and Opening-up 改革开放以来党的历届四中全会主题回顾, 11 J. DALIAN OfFICIAL 大连干部学刊 17-8 (2014).

51. Lingling Li \& Yaohui Zhang, Assessment and Construction of the Transformation Pattern of China's Economic Growth 我国经济发展方式转变测评指标体系的构建及初步测评, 4 CHI. INDUSTRIAL ECO. 中国工业经济 54-5 (2011).

52. Hao Dong \& Kun Wang, Target and Path of Judicial System Reform in China--Interpretation 
of Judicial System Reform of the Third PS of the 18th 我国司法体制改革的目标与路径--关于 十八届三中全会司法体制改革精神的解读, 1 ADMIN. L. REV. 行政法学研究 6 (2014).

53. The "Comprehensive Well-off Society" target is the ultimate target of China in 2020. The target concerns economic, political, social, ethics and ecologic construction.

54. See PCC Decision on Certain Significant Issues Regarding the Promoting the Governance of the Country by Law 中共中央关于全面推进依法治国若干重大问题的决定, XINHUA NEws, Oct. 28, 2014, available at http://news.xinhuanet.com/politics/2014-10/28/c_1113015330. htm; The PCC Decision on Certain Significant Issues Regarding the Promoting the Governance of the Country by Law 中共中央关于全面推进依法治国若干重大问题的决定, State Council of China (Oct. 28, 2014), available at http:/www.gov.cn/xinwen/2014-10/28/ content_2771714.htm (all last visited on Jan. 30, 2016).

55. See PCC Decision on Certain Significant Issues Regarding the Promoting the Governance of the Country by Law 中共中央关于全面推进依法治国若干重大问题的决定, Reformdata website (Oct. 28, 2014), available at http://www.reformdata.org/content/20141028/27383.html (last visited on Feb. 8, 2016).

56. Id. $\S \S 2-5$.

57. Id. $\S 3$ (Further the Promotion of Administration by Law, Fasten the Construction of the Government Ruled by Law).

58. Explanation of the PCC Decision on Certain Significant Issues Regarding the Promoting the Governance of the Country by Law.

59. The district is administrative district in China, which refers to provincial district, prefecture district, county district, township district and village district.

60. People's Court and People's Procuratorate in China have generally been erected (excluding the special courts and procuratorates: e.g., railway court/procuratorate and military court/ procuratorate) according to the administrative regions above, rather than the cross-district before the publication of the PCC Decision. Generally, each People's Court/People's Procuratorate is corresponding to a level of administrative government. The Supreme People's Court and People's Procuratorate therefore initiated the "Experimental Plan to Establish the Cross-district People's Court and People's Procuratorate," which changed the rules setting up Courts and Procuratorates. For details on the Establishment of the administrative district-based Courts and Procuratorates, see Articles 17, 22 and 25 of the Organic Law of the People's Courts of the People's Republic of China 中华人民共和国人 民法院组织法 (2006 Amendment); Articles 22 and 23 of the Organic Law of the People's Procuratorates of the People's Republic of China 中华人民共和国人民检察院组织法 (1983 Amendment).

61. The first cross-administrative district court and Procuratorate in China were established on December 28, 2014, which results from the PCC Decision over the constructions of the judicial system. See Jianping Wei, The First Cross-Administrative District Court and Procuratorate Are Established in Shanghai 上海设立全国首个跨行政区划人民法院和人民检 
察院, China Court website (Dec. 29, 2014), available at http://www.chinacourt.org/article/ detail/2014/12/id/1525213.shtml (last visited on Feb. 8, 2015).

62. Zhai Shen, Historical Analysis of Chinese Law 近现代中国法律发展的历史分析, 6 NEw ACAD. F. 新学术论坛 26 (2008).

63. PCC Decision on Certain Significant Issues Regarding the Promoting the Governance of the Country by Law.

64. Zhenghua Li, Comments on the Research of the Third PS of the 11th PCC 中共十一届三中全 会研究述评, 15 ConTEMP. China Hist. Stud. 当代中国史研究 73-5 (2008).

65. In international investment arbitration, the investors usually support the claims by citing how the host states' behaviors and procedures are inconsistent with the investment treaty. In this process, the more details (regarding how the administrative authorities reach decisions) investors can access, the more sufficient the evidence is to support the claims. See C. Brower, Evidence before International Tribunals: The Need for Some Standard Rules, 28 INT'L LAW. 49 (1994).

66. Jun Zhao \& Ming Hu, A Comparative Study of the Legal Education System in the United States and China and the Reform of Legal Education in China, 35 Suffolk Transnat'l L. Rev. 348 (2012).

67. Jinming Xiao, Questioning the Legal Education in China: Problems and Solutions, 考问中国 法学教育: 问题与对策, 6 J. SHANDONG UnIV. 山东大学学报 17 (2011).

68. Xiangde Ji, Comprehensive Rethinking and Outlook of Chinese Legal Education 对中国 法学教育全面反思与展望, 18 J. CHINA UNIV. POL. SCI. \& L. 中国政法大学学报 53 (2010) (It provides: "Nearly all the universities in China provide legal education, which increases the member of law school student but does not keep the pace with the growth of legal education resources.")

69. Jianmin Chen, The Status and Function of Clinical Legal Education: from the Perspective of the Purpose of Legal Education 从法学教育的目标审视诊所法律教育的地位和作用, 3 GLOBAL L. REv. 环球法律评论 284 (2005). (It provides: “The purpose of legal education in China is unclear, as a result of which the practical teaching is overlooked.")

70. China-Uzbekistan BIT 2011 art. 2.1. It reads: "Each Contracting Party shall encourage investors of the State of other Contracting Party to make investments in the territory of its own State and admit such investments in accordance with its laws and regulations." See also China-Norway BIT 1984 art. 2. It reads: "This agreement shall be applicable to investments made by nationals or companies of the PRC in the territory of the Kingdom of Norway in accordance with its laws and regulations and investments made by nationals or companies of the Kingdom of Norway in the territory of the PRC in accordance with its laws and regulations both before and after the entry into force of this agreement."

71. J. Hepburn, In Accordance with Which Host State Laws? Restoring the 'Defence' of Investor Illegality in Investment Arbitration, IISD Investment Treaty News (Nov. 19, 2014), available at http://www.iisd.org/itn/2014/11/19/in-accordance-with-which-host-state-laws- 
restoring-the-defence-of-investor-illegality-in-investment-arbitration (last visited on Feb. 8, 2016).

72. Id.

73. Youwu Chen \& Buyun Li, The Development of Rule by Law and Human Rights after the Reform and Opening-up 改革开放以来法治与人权关系的历史发展, 37 MoD. L. SCI. 现代法学 8-9 (2014).

74. Mingan Jiang, Improvement of the Legislative System, and the Highlights of the Law of Legislation 改进和完善立法体制《立法法》呈现七大亮点, 4 Admin. MGMT. REFoRm 行政管理 改革 23 (2015).

75. The local authorities entitled to enacting regulations and rules may be driven by the local protectionism, which in turn can be reflected in the legal instruments accordingly. See J. Alvarez, Political Protectionism and United States International Investment Obligations in Conflict: The Hazards of Exon-Florio, 30 VA. J. InT'L L. 15 (1989).

76. The author would argue that the stability of Chinese domestic legal framework might be undermined in the reforms, which may eventually influence the investors' predictability of China's laws before their decisions to invest in China.

77. E.g., the 1994 Energy Charter Treaty art. 10. It reads: "Each Contracting Party shall ... encourage and create stable, equitable, favorable and transparent conditions... Such conditions shall include a commitment to accord at all times to Investments of Investors of other Contracting Parties fair and equitable treatment." See also L. Boisson de Chazournes, Transparency and Amicus Curiae Briefs, 5 J. World Inv. \& Trade 333 (2014); F. Francioni, Access to Justice, Denial of Justice and International Investment Law, 20 EuR. J. INT'L L. 740 (2009); C. Schreuer, Fair and Equitable Treatment in Arbitral Practice, 3 J. WorLd Inv. \& TRADE 373-80 (2005).

78. Explanation of the PCC Decision on Certain Significant Issues Regarding the Promoting the Governance of the Country by Law.

79. The laws regulating foreign investments are the Sino-Foreign Joint Venture Law, Foreign Enterprise Law and Sino-Foreign Cooperative Law, which were enacted in the early stage of the 'Open-up' policy. However, China is drafting the new law of "Foreign Investment Law of the PRC" to replace the three laws. See The Exposure Draft of the Foreign Investment Law of the PRC 中华人民共和国外国投资法 (草案征求意见稿) Ministry of Commerce website (Jan. 19, 2015), available at http://tfs.mofcom.gov.cn/article/as/201501/20150100871010. shtml (last visited on Jan. 20, 2016).

80. Id.

81. PCC Decision $\$ 2.4$.

82. Id.

83. FPS $§ 2$ (Improve the Socialist Legal System Centring on the Constitutional Law, Strengthen the Enforcement of Constitution) 4 (enhancing the legislation in key fields).

84. Id. 
85. The Two-100 Year goals were raised at the 18th PCC as the development targets of China. The first 100-year refers to the 100 years from the establishment of the Communist Party in 1921, when the "comprehensive affluent society" would be established. The second 100year refers to the 100 years from the establishment of the PRC from 1949, when a 'modern' China with wealth, democracy, civilization and harmony is expected. See Jidong Zhu, The Difference between Chinese Dream and American Dream” 中国梦” 和 “美国梦” 的差异在哪 里, 2 PARTY CONSTRUCTION 党建28 (2013).

86. Yongxiu Bai \& Songji Wang, Reconstruction of the Core of Economic Reform in China: the Interaction of the Government and the Market 我国经济体制改革核心重构: 政府与市场关 系, 7 Reform 改革14 (2013). See also Guizhen He et al., Changes and Challenges: China's Environmental Management in Transition, 3 Envtl. Dev. 28 (2012); W. Morrison, China's Economic Conditions, 21 Current Pol. \& Econ. N. \& W. Asia 297 (2012).

87. The withdrawals from the ICSID mechanism by Venezuela, Ecuador and Bolivia and the abolishment of BITs are reflecting their need to review the current investment instruments in order to achieve a more 'balanced' treaty framework. See S. Ripinsky, Venezuela's Withdrawal from ICSID: What It Does and Does Not Achieve, IISD InVESTMENT TREATY News, Apr. 13, 2012, available at http://www.iisd.org/itn/2012/04/13/venezuelaswithdrawal-from-icsid-what-it-does-and-does-not-achieve (last visited on Feb. 8, 2016).

88. See A comprehensive reading of the National Security Committee of the PRC 全方位解读 “中 央国家安全委员会” 和 “总体国家安全观,” China Reform, Apr. 17, 2014, available at http:// www.chinareform.org.cn/gov/governance/Practice/201404/t20140417_194837.htm (last visited on Feb. 8, 2016).

89. See Jinping Xi assumes the chairman of the national security committee of the PRC 习近平任 中央国家安全委员会主席, China.org.cn, Jan. 25, 2014, available at http://www.china.org.cn/ chinese/2014-01/25/content_31303165.htm (last visited on Feb. 8, 2016).

90. Ralls Corporation v. Committee on Foreign Investment in the United States Et Al, United States District Court for the District of Columbia, Civil Action No. 12-1513 (ABJ), available at https://www.gpo.gov/fdsys/granule/USCOURTS-dcd-1_12-cv-01513/USCOURTS-dcd1_12-cv-01513-1/content-detail.html (last visited on Feb. 9, 2016).

91. Yiheng Feng, We wouldn't Transfer Title to the Devil: Consequences of the Congressional Politicization of Foreign Direct Investment on National Security Grounds, 42 N.Y.U. J. INT'L L. \& Pol. 272 (2009).

92. M. Rogers \& D. Ruppersberger, Investigative Report on the U.S. National Security Issues Posed by Chinese Telecommunications Companies Huawei and ZTE, US House of Representatives 112th Congress (2012), available at https://intelligence.house.gov/sites/ intelligence.house.gov/files/documents/Huawei-ZTE\%20Investigative\%20Report\%20 (FINAL).pdf (last visited on Feb. 8, 2016).

93. PCC Decision $₫ 6$, pt. 2.4.

94. See A Comprehensive Reading of the NSC of the PRC and the General National Security 
全方位解读 “中央国家安全委员会” 和 “总体国家安全观,” XINHUA NEWs, Apr. 17, 2014, available at http://news.xinhuanet.com/politics/2014-04/17/c_126397122.htm (last visited on Feb. 8, 2016).

95. The Exposure Draft of the Foreign Investment Law of the PRC, supra note 79.

96. Zelin Su, The Significance to Establish the People's Courts Crossing the Administrative Regions 跨行政区划设立人民法院的法治意义, People's Court News (Oct. 27, 2014), available at $\mathrm{http}: / / \mathrm{rmfyb} . c h i n a c o u r t . o r g / p a p e r / h t m l / 2014-10 / 27 /$ content_89720.htm?div=-1 (last visited on Feb. 8, 2016).

97. PCC Decision $\S 4$.

98. Supra note 13, at 10-6. See also China-UK BIT (1986) art. 7(1); China-New Zealand BIT (1988) art. 13(3); Australia-China BIT (1988), art XII. 2.

99. Supra note 13 , at 10.

100. F. Francioni, Access to Justice, Denial of Justice and International Investment Law 20 EuR. J. InT'L L. 1079-82 (2009).

101. China-Colombia BIT (2008) art. 9. It reads: "With regard to acts of a governmental authority, in order to submit a claim to arbitration under this article or to domestic court, domestic administrative remedies shall be exhausted..."

102. Belgium-Luxembourg Economic Union and China BIT (2005) art. 8. It "requires that the investor concerned exhausts the domestic administrative review procedure."

103. Protocol to the China-Latvia BIT (2004) Ad art. 9; Protocol to China-Netherlands BIT (2001) Ad art. 10; Protocol to the China-Tunisia BIT (2004) Ad art. 9.1.

104. See China-Djibouti BIT (2003) art. 9; See also China-Guyana BIT (2003); China-India BIT (2006); and China-Trinidad and Tobago BIT (2002). Those BITs have the same expressions. See also China-Myanmar BIT (2001) art. 9 (b). It reads: "An ad hoc arbitral tribunal provided that the Contracting Party involved in the dispute may require the investor concerned to exhaust the domestic administrative review procedure specified by the laws and regulations of that Contracting Party ... if the investor concerned has resorted to the procedure specified in Paragraph 2 of this Article the provisions of this Paragraph shall not apply."

105. Protocol to China-Finland BIT (2004) Ad art. 9. It reads: "The People's Republic of China ... may require the investor concerned to exhaust the domestic Administrative Reconsideration procedure specified by the laws and regulations of the People's Republic of China before submission of the dispute to the arbitration procedures..."

106. P. Peters, Exhaustion of Local Remedies: Ignored in Most Bilateral Investment Treaties, 44 Neth. Int'L L. Rev. 233-4 (1997).

107. C. Schreuer \& R. Dolzer, Principles of International Investment Law 76 (2008).

108. S. Mavluda, Return to the Local Remedies Rule in European BITs? Power (Inequalities), Dispute Settlement, and Change in Investment Treaty Law, 39 Legal Issues Eco. INTEGRATION 230 (2012). 
109. Id. at 230 .

110. Id. at 226-30.

111. The cases of Loewen v. United States and Saipem v. Bangladesh reflected the international tribunals' bias towards the judiciary in developed States. The Loewen tribunal maintained that the local remedies in the US should be exhausted by investors even though the tribunal recognized that the jury in the US court had been influenced by persistent appeals to local favoritism as against a foreign litigant. The Saipem tribunal, however, held that the investors exhausted all the reasonable remedies in Bangladesh because the investor spent considerable effort and money in litigation, although the investor did not make resort to all the available appeals in Bangladesh. See The Loewen Group, Inc. and Raymond L. Loewen v. United States, ICSID Case No. ARB(AF)/98/3 (Award of June 26, 2003); SAIPEM S.p.A. v. Bangladesh, ICSID Case No. ARB/05/7 (Award of June 20, 2009), I 181. For details, see M. Sattorova, Denial of Justice Disguised? Investment Arbitration and the Protection of Foreign Investors from Judicial Misconduct, 61 INT'L \& Comp. L.Q. 227 (2012). See also supra note 100, at 1078-81.

112. Supra note 108 , at $226-30$.

113. Committee on International Trade of European Parliament, Report on the Future European International Investment Policy (Mar. 22, 2011), available at http://www. europarl.europa.eu/sides/getDoc.do?pubRef=-//EP//TEXT+REPORT+A7-20110070+0+DOC+XML+V0//EN (last visited on Feb. 8, 2016).

114. R. Pardo, ISDS and TTIP - A Miracle Cure for A Systemic Challenge?, European Policy Centre Policy Brief website (July 14, 2014), available at http://www.epc.eu/documents/ uploads/pub_4637_isds_\&_ttip_-_a_miracle_cure_for_a_systemic_challenge.pdf (last visited on Feb. 8, 2016).

115. See Juncker Promises Careful Look at US Trade Deal, EU Bus. News, Oct. 22 2014, available at http://www.eubusiness.com/news-eu/us-trade-treaty.ycu (last visited on Feb. 8, 2016).

116. Pinsent Masons Legal News, Germany Plans to Block ISDS Clause in Transatlantic Trade Deal, Out-Law Legal News website (Mar. 18, 2014) available at http://www.out-law.com/ en/articles/2014/march/germany-plans-to-block-isds-clause-in-transatlantic-trade-deal (last visited on Dec. 29, 2015).

117. See German Contention Overshadows EU-Canada Trade Deal, German DW News, Sept. 25, 2014, available at http:/www.dw.de/german-contention-overshadows-eu-canadatrade-deal/a-17957308 (last visited on Feb. 8, 2016).

118. In Elettronica Sicula Spa, the ICJ maintained that: “....in the present case, however it was for Italy to show, as a matter of fact, the existence of a remedy which was open to the United States stockholders and which they failed to employ. The Chamber does not consider that Italy has discharged that burden." See Elettronica Sicula Spa (ELSI) (U.S. v. Italy), Judgment 1989 I.C.J. 61 \& 62 (July 20). In Ahmadou Sadio Diallo, the ICJ also 
maintained that: "It is for the respondent to convince the Court that there were effective remedies in its domestic legal system that were not exhausted." See Ahmadou Sadio Diallo (Guinea v. Congo), Judgment 2007 I.C.J. 44 (May 24) (Preliminary Objections). 